Веселин Булатовић

Учитељски факултет

Докторске студије Методике разредне

наставе, Ужице

ЈУ ОШ „Алекса Ђилас Бећо” Мојковац

kostanabp@t-com.me

\title{
МЕТОДИЧКИ ПРИСТУП ДРАМИ КОШТАНА БОРИСАВА СТАНКОВИЋА
}

\begin{abstract}
АПСТРАКТ
Предмет рада „Методички приступ драми Коштана Борисава Станковића" подразумијева свеобухватно сагледавање драме и изналажење методичких приступа у тумачењу њене тематске, естетске, стилске и идејне структуре. У методичкој теорији и пракси, како код нас, тако и у свијету, постоји читав низ поступака који се примјењују у тумачењу књижевног дјела. Кроз примијењени методички поступак наглашен је значај овог жанра у савременом тренутку науке о књижевности и у наставној пракси, то јест потврђена је чињеница да без изграђеног методичког система нема успјешног увођења ученика у свијет конкретног књижевног дјела, као ни разумијевања и изграђивања афинитета према књижевној умјетности. Добро осмишљен методички приступ обезбјеђује успјех у тумачењу књижевног дјела и ствара неопходне претпоставке за даље свестрано изграђивање и образовање ученика. На тај начин ученици се оспособљавају да самостално улазе у свијет књижевног дјела, да логички размишљају и доносе сопствене закључке и судове.
\end{abstract}

Кључне ријечи: методички приступ, драма, драмска акција, истраживачки задаци.

\section{METHODICAL APPROACH TO THE DRAMA KOŠTANA BY BORISAV STANKOVIĆ}

\begin{abstract}
The subject of the paper "Methodical approach to the drama Koštana by Borisav Stanković" implies comprehensive understanding of the drama and finding methodical approaches in the interpretation of its thematic, aesthetic, stylistic and conceptual structure. In methodical theory and practice both in our country and abroad there are a number of procedures
\end{abstract}


that can be applied in the interpretation of literary works. Through the applied methodical procedure the importance of this genre is emphasized in the contemporary moment of literary studies and in the teaching practice, i.e. it is confirmed that without the constructed methodical system there is no successful introduction of students to the world of a particular literary work and there is no understanding and building affinity for literary arts. A well designed methodical approach ensures success in the interpretation of literary works and creates the necessary preconditions for further comprehensive building and education of students. In this way, students are trained to independently enter the world of literary works, to think logically and make their own conclusions and judgments.

Keywords: methodical approach, drama, dramatic action, research assignments.

\section{1. УВОД}

У складу са предметним програмом за црногорски језик и књижевност, драма Коштана Борисава Станковића предвиђена је за анализу у трећем разреду средње школе. Неопходно је да ученици претходно прочитају текст драме и да са свјежим утисцима о њој дођу на час. Гледање позоришне представе веома је значајно за потпуније схватање и разумијевање исте. Али, без обзира на то што анализу драмског дјела не треба мијешати са анализом његове позоришне представе, велика је штета што већина ученика није у реалној могућности да свој доживљај Коштане обогате гледањем позоришне представе овог изузетног драмског остварења. „У школској пракси превладава литерарна концепција, која понекад недовољно афирмира посебност драмског текста, тј. своди драмско дјело на епске елементе (епизација драмског дјела)““(Rosandić 1978: 125).

Циљеви обраде драме у вези су са представљањем творца модерног романа Борисава Станковића, доживљајно и аналитичко-синтетичко проучавање драме, уочавање и детаљно анализирање теме, ликова и основне идеје дјела. Такође, у оквиру васпитно-образовних циљева неопходно је помоћу естетских и идејних вриједности драме развијати код ученика смисао за лијепо и племенито у умјетности и животу. Важно је да ученици обнове књижевно-теоријске појмове из области драмског стваралаштва.

Код формулисања функционалних циљева приоритет имају специјални истраживачки задаци кроз које се ученици навикавају на самосталан истраживачки приступ дјелу. У процесу анализе драме неопходно 
је развијати код ученика смисао запажања основних умјетничких посебности текста, смисао за критичко продирање у његову структуру и давање оригиналних и поузданих закључака са личног становишта. Навикавати ученике да умјетничке утиске аргументују одговарајућим чињеницама из текста и да самостално процјењују њихове умјетничке квалитете. „Доживљај књижевног дела толико је сложена и значајна појава да само његово саопштавање, поткрепљивање и осветљавање са разних становишта може да представља ваљану књижевну анализу (Николић 2006: 292).

На тај начин ће се код ученика побудити интересовање за читање и других књижевних остварења Борисава Станковића. Такође, у непосредној вези са доживљајном анализом Коштане, неопходно је подстаћи ученике да и они, у облику домаћег задатка, изнесу своје схватање положаја појединца у породици и друштвеној средини у којој живи.

\section{2. НАСТАВНА ОБРАДА СТАНКОВИЋЕВЕ КОШТАНЕ}

С обзиром на то да су ученици благовремено обавијештени да прочитају драму, то је и идеална прилика да им подијелимо специјалне истраживачке задатке који ће им бити од користи да своје мисли, доживљаје и утиске о дјелу организују, те да се на тај начин припреме за активно учешће у књижевној анализи на часу. Такође, сугерисано им је да приликом читања биљеже појединости које ће им послужити при анализи ликова. Имајући у виду чињеницу да је једна од најљепших чаролија Станковићевог позоришта болна, искрена, чежњива поезија самоисповијести кроз коју се оцртавају ликови у драми, обраду исте засновали смо на анализи ликова.

„Колико драмски лик може бити упечатљив и оставити трајне трагове у свести читалаца/гледалаца, казује чињеница да су многи драмски ликови постали стални симболи оних људских особина које су они у драми испољили као доминантне црте својих карактера“ (Илић 1998: 422).

- Прочитајте драму Коштана у цјелости.

- Припремите се да презентујете свој умјетнички доживљај драме (осјећања, утиске, мисли и расположења).

- Припремите се да истакнете све битније појединости садржаја Коштане. Уочите битне карактеристике драмске фабуле.

- Наведите главни проблем кроз који се испољавају јунаци овог дјела. Какво разрјешење у вези са тим налазите? 
- Уочите карактерне особине ликова из драме и припремите се да примјерима из текста то илуструјете.

- Коштана оличава младост и љепоту; створена је за пјесму и игру, а шта је очекује?

- Митке, наизглед бекрија, носи у себи велики расцјеп личности; на оно што је некад био и што сада јесте. Како доживљава ту промјену?

- Покушајте да објасните шта спаја, а шта раздваја све ликове у драми.

- Осмислите дебату која ће бити у вези са основном идејом и поруком драме. Размишљајте о положају данашњег човјека и о могућностима остваривања личне слободе у нашем времену и нашој средини.

- С обзиром на то да је драма Коштана писана језиком који је дијалекатски обојен, који је најархајичнији по својој лексици, облицима и синтакси, потрудите се да пронађете непознате ријечи и да одредите њихово значење.

У уводном дијелу часа ученици ће презентовати неке најбитније појединости из живота и рада Борисава Станковића. Указаће на то да је Станковић изразити регионалиста по тематици, а по поступку, стилу и унутрашњој, психолошкој перспективи у начину приказивања, представља зачетника српске модерне прозе. Дубоко увјерен да права ријеч извире из живота који он воли и разумије, Борисав Станковић се није удаљавао од поетичне и егзотичне оазе свога Врања. „Он је волео боје врањског поднебља и мирисе врањског живота, зато што су то били мириси и боје његовог детињства“ (Протић 1972: 355).

„Поред географског, историјског, социјално-етнографског и културног значења што га је имало за његову реалистичку свест о важности средине, расе и менталитета, Врање је Станковићу помогло да једном тесном и забаченом кругу света, глувој касаби незнаног вилајета, удахне универзално значење уметничког симбола који поред естетског има још и духовно, метафизичко и надисторијско дејство. У том малом простору дешавају се велике космичке катастрофе људског битисања" (Палавестра 1986: 430).

Посебно је важно да ученици уоче да је Станковић у својим дјелима дао реалну слику времена о којем је писао, али и да истакну да је основна одлика његовог приповједачког стваралаштва свестрано освјетљавање човјековог психичког живота. У средишту његових дјела налази се човјек и његова судбина, а у приказивању својих јунака спуштао се до слојева 
подсвјесног. Приказујући многобројне јунаке и њихове судбине, писац је дубоко ушао у њихову психу и освијетлио њихове најскривеније тајне.

Даљи наставак часа биће посвећен казивању непосредних умјетничких доживљаја и утисака. Питања могу бити формулисана на сљедећи начин:

- Изнесите своје утиске након завршетка читања драме Коштана. Како сте се осјећали док сте је читали?

- Покушајте да објасните откуд потичу ова супротна осјећања која Коштана у нама изазива. Шта вас у судбинама јунака и њиховим трагичним разрјешењима највише узбуђује и зашто?

Очекујемо да ученици презентују своје утиске који су изазвани читањем драме. Ту се превасходно мисли на осјећање радости, заноса и опијености младошћу, љубављу и љепотом. Али, исто тако, они ће указати да их је истовремено обузимала бол, туга и револт због супротних осјећања, недостатака личне среће и злих судбина главних јунака. Ликови су у сталном међусобном неразумијевању и сукобу - сукоб је међу њима, али сукоба има и у ьима. Констатоваћемо да је драма изазвала супротна осјећања: радост је помућена болом, љубав подсјећа на смрт, а заносна пјесма се претаче у уздах, сузе и болни вапај. Доминантни проблем који чини суштину драмског сукоба, а кроз који се испољавају ликови овог дјела, јесте однос (побуђене) јединке и (патријархалног) друштва. Добрим методичким вођењем наставник усмјерава ученике како би схватили да сложене и опречне емоције потичу од сукоба тежњи, жеља и страсти појединих ликова у драми са строгим патријархалним моралом средине која гуши глас срца и љубави и омета нормално испољавање личности.

„Сав немир што су га у варошици унели Коштанина песма и лепота, изражен у сукобу њених поклоника са породицом, влашћу, друштвом и чаршијом, био је подстакнут и појачан неиживљеним, промашеним младостима, хаџи Томином и Митковом" (Палавестра 1960: 12).

Код Станковића је друштвена средина строга и неумољива сила која својим тамним патријархалним моралом и низом неписаних закона унапријед одређује живот сваког појединца, имајући у виду, у првом реду, 
класну и социјалну припадност. Ученици запажају да од тих односа страдају сви ликови у Коштани ${ }^{1}$ :

- И младалачки устрептала Коштана која за клетвом полази за Асана, да гине, да вене поред мужа за ког је силом удају. Пјесма и слобода су смисао њеног трајања, али у томе нема ничег што би било разголићено, лишено самоконтроле, што би било лукаво или похотно и грамзиво. Одбија Стојанову љубоморну љубав, богаташку кућу и старе родитеље:

„Нећу! Не могу! Код тебе! Зар само код тебе? И само хаџију, оца твога и мајку твоју да дворим и да служим? Да пред њима клечим и ноге да им перем? Из собе да не изађем, већ само да седим, ћутим, трпим?“ (Станковић 1983: 69).

Није она за то, „само” горе је и од Бање, и од Асана, и од циганске махале. Јер: „...Кад ноћ падне, месечина дође, сан не хвата, око се шири, снага разигра...шта онда? ... Зар да се не мрднем, из собе не изађем, већ само ту да седим, ћутим, гледам у месечину... А ноћ дубока, месечина иде, греје, удара у чело, главу... пали... Шта онда?... Ох, нећу”. (Станковић 1983: 69).

- И поетски занесени Митке ${ }^{2}$ који толико воли живот да ће у гроб „са отвореним очима” да легне, зато куне породицу која га „закла”, „зароби”, и која је од њега створила бившег човјека и бекрију који се на крају комада повлачи у дим и пепео; Митке осјећа да долази старост, тијело је ослабило а душа је још жељна и болна. „Дерт” носи од механе до механе, у пјесми и вину га утапа. Он болује од тешког, големог карасевдаха, а срце још „за лепотињу и убавињу, гине и вене”. (Станковић 1983: 59).

Своју пјесму у ноћи чује и у сну сања: „А песма је моја голема: Како мајка сина имала, чувала, ранила. Дан и ноћ само њега гледала. Што на сина

\footnotetext{
${ }^{1}$ Станковић је појединим својим јунацима давао имена људи који су заиста постојали, али мијењао је њихове особине, дограђивао њихове карактере и судбине. Познато је да је у Врању живио боем сличан Митку, онако као и Митка, чак је, у очајању због сивила и тежине живота извршио самоубиство. Такође, живјела је и пјевачица Коштана, баш под тим именом у Врањској Бањи, и представљала се бањским гостима као „Борина Коштана“. Али, неопходно је имати у виду да Коштана није грубо пресликавање сурових детаља живота једне средине, а самим тим ни Коштана као књижевни лик није фотокопија личности из стварног живота. Чињеница је да је Станковићево дјело далеко надрасло прост животни факат и добило универзално значење.

2 Према мишљењу југословенских критичара и театролога, Митке је, независно од сижеа, главна личност Коштане. С правом је запажено да је многе од својих погледа на живот и срећу Станковић исказао у овом лику. А оно што је Скерлић исписао као карактеристику овог Станковићевог јунака остало је, у основи, оцена наших критичара и театролога до данас (Марјановић 1985: 13).
} 
душа заискала, све мајка давала, а син - болан! Пораснаја син. Дошла снага, младост... Дошле башче, цвеће, месечина - Замирисале девојке! ...Син полетаја. Све што искаја, све имаја. Хатови, пушке, сабље, жене... Коју девојку неје погледаја само њојне косе неје замрсија и уста целиваја. Ниједна му не одрече, ниједна га не превари, а он све ги целиваја, све вараја и - болан бија. Болан откако се родија - То сам ја!...“ (Станковић 1983: 58).

- И разњежени Стојан чију младост крути друштвени закони унесрећују јер не смије да воли жену коју је сам изабрао.

- И хаџи-Тома, домаћин, трговац, хаџија, представник управо тог старог деспотског, патријархалног морала, и сам жали због наметнутог му живота и оне „старе, мртве, ледне, плачне”. Откада се оженио није ишао у механе јер се бојао да га не виде стари људи, трговци. Током цијелог живота стицао је богатство да би га оставио сину. Не жали што син Стојан расипа, што носи свилу и срму. Љути га што када дође кући из хана, на свети дан да га проведе с породицом и пријатељима, сина затиче у механи с Циганкама, а жену Кату како само плаче и кука. Жену криви за све. Забрањује јој да говори јер никада ништа није ни знала, никада није ни била за хаџијску кућу. Наметнули су му је родитељи и обзири, он је никада није волио, увијек му је била далека: „Откако си, таква си. И родила си се таква! Стара, мртва, ледена, плачна... Никада се не насмеја, никада се не зарадова!“ (Станковић 1983: 28).

- Која вам се сцена највише свидјела? Које вас је мјесто у драми посебно одушевило?

- Ко се још исповиједа у Коштани? Ко још жали за младошћу, или ће жалити? Шта је тема драме Коштана?

Подстакнути и довољно мотивисани ученици ће наводити сцене које су код њих изазвале најјачи утисак. Посебно ће указати на Митков дијалог из трећег чина у коме он говори о својој младости. Али, ученици уочавају да су поред Митка исповиједању склони и хаџи Тома, Коштана и Стојан. Жал за младошћу пустоши душом хаџи-Томе и Митка, а код Коштане и Стојана тек се зачиње и наслућује. Констатују да је тема драме жал за младошћу. Другачије речено, у Коштани се заправо преплићу двије велике теме цјелокупног Станковићевог стваралаштва, туга за прохујалом младошћу, „жал за младост” и чулна опсесија женском љепотом. Ове теме сублимиране су овдје у трећој - теми пјесме. Народне пјесме које пјева Коштана носе у себи чежњу за љепотом и пуним животом ослобођен свих стега, пун радости 
и пустоловина, оне су уточиште од сивила прозаичне стварности лишене сваке љепоте, од брака који је тамница. Сви ликови у драми испуњени су том чежњом за љепотом, љубављу и потпуним, интензивним, слободним животом.

„Истраживачи Станковићева књижевног опуса запазили су неколико његових основних тема: пролазност живота и љубави, ‘жал за младост ' (или, прецизније: ‘жаљење за оним што није било, што се није имало ни остарило, што се промашило'), тежња да се 'негде` оде, јер живот који се живи није прави” (Марјановић 1985: 10).

Претходни дијалог са ученицима представља солидну емоционалну и сазнајну основу за прелазак на конкретну анализу драме. Прво ћемо вршити анализу ликова. Упућујемо ученике да открију доминантне карактерне црте главних ликова. Настојаћемо да се уочавањем доминантних ликова и поступака ,расутих” по тексту, дају монолитне слике ликова и њихових карактера.

- Одредите главне ликове у драми Коштана. Која од њих има примарну улогу? Зашто?

Неопходно је да ученици објасне зашто је Миткова улога примарна у драми. Митке доминира својом емоционалношћу, поетским исповиједањем и рефлексијама о људској судбини и животу. Љетопис старог Врања помиње Митка дућанџију, који је поред „слатке туге” за минулом младошћу знао и за свој ћепенак са ужаријом. У драми Коштана он презире и дућан и кућу. Незадовољство собом и другима не може му ублажити трговачко богатство. Он је богаташ племенитог бола, а не трговац који за зараду живи. Као младић није му било равна од Скопља до Солуна; када је царским друмом ходио све му се живо склањало са пута. Када су му „замирисале” дјевојке, много је уста пољубио.

„Све што искаја, све имаја. Хатови, пушке, сабље, жене... Коју девојку неје погледаја, само њојне косе неје замрсија и уста целиваја. Ниједна му не одрече, ниједна не превари, а он све ги целиваја, све вараја и - болан, болан бија. Болан откако се родија” (Станковић 1983: 63).

- Шта Митке каже о себи када је осјетио да га напушта младост? (Ученици читају мјеста из Митковог монолога).

- Зашто Митке толико жали за младошћу? 
Поезија је једино уточиште за Митка. У поезији он слободно трага за одбјеглом младошћу и ускраћеним слободама. Његова пјесма је крвави уздах за празном и пустом младошћу „што у ништо отиде”.

„Функција и значај песме и певања у драми се указују у потпуности, јер мелос у њој добија своју највиталнију димензију - звучну. Нарочито у драми Коштана, у којој се тридесет и један пут све предаје Коштанином гласу. Додуше, сценска функција песме и певања може се различито процењивати - од извођења до извођења. Ову резерву ваља задржати, јер су управо мелички елементи најчешће заводили родитеље на фолклористичке странпутице. Такву опасност предочио је Јован Скерлић својим првим утиском са премијере: „Када се завеса подигла, појавио се буљук белих Врањанки. Шалваре су зашуштале, дукати зазвецкали, и запевало је ‘Шано душо, Шано...' Ја помислих да ћемо имати да гледамо нешто као Ђидо, Риђокоса, Потера, низ шарених 'слика из народног живота' са много песама и игара, и са обавезном свадбом на крају...“(Јовичић 1969: 549).

Ученици ће Миткову носталгију за младошћу образлагати у смислу: Митке жали за младошћу јер је почео да стари и све више осјећа физичку немоћ. Мотиви који су га заносили у младости (сабље, коњи, пушке, жене нијесу га сасвим напустили), али је најболније што они, силом физиолошких процеса, постају све беспредметнији. Ученици своје тврдње поткрепљују цитатима из дјела.

Наравно, неопходно је нагласити да се Митков жал за младошћу не може објаснити само као посљедица старења, јер је он знатно сложенији и дубљи. Инсистирамо да ученици открију социолошке мотиве Митковог понашања и жала за младошћу.

- Шта је узроковало тако трајан бол и стално незадовољство код Митка?

- Какав је његов положај у породици и друштву?

- Који је животни (психолошки) мотив стално спутаван и потискиван?

- Како неостварени мотив личне афирмације дјелује на Митково понашање? Како се тај мотив трансформисао, преносио, компензирао?

Ученици ће истаћи да је Митке потцијењен и запостављен у породици и патријархалном друштву, па стога задовољење мора да тражи на другој страни. Када је већ спријечен да стекне углед и признање у чорбаџијско-хаџијској средини којој припада, он трага за погодним 
условима у којима може лакше да се истакне и гдје ће његова личност нешто представљати. У тим новим околностима, подстакнут алкохолом и пјесмом, он покушава да ублажи своју тугу и бол.

Миткову чежњу за личном слободом и неограниченим правима срца ученици илуструју и коментаришу уз помоћ сљедећег одломка:

„Ноћ летња. Шар-планина у небо штрчи, а испод њума легло пусто и мртво Косово. Друм широк, прав, царски. По њега се расипали ханови, сераји, башче, чесме. Месечина греје... Мартинка ми у крило, коњ, Дорча мој, иде ногу пред ногу...“ (Станковић 1983: 63).

Ученици запажају да је истицањем Шар-планине која у небо штрчи, пустог и мртвог Косова и широког царског друма, у љетњој ноћи и на мјесечини, сугерисана бесконачност простора. Осјећање неограничене ширине и бескрајности идеална је експресија за Миткову неодољиву чежњу за личном слободом и бјежањем од уских и стијешњених оквира патријархалне средине. Митке је овдје, као и у већини својих монолога, маштар који се својим сензибилитетом и исповијестима уздиже до правог лирског пјесника.

- Зашто Митке престаје са ранијим боемским животом? Како он доживљава ову промјену?

- Усваја ли Митке норме патријархалног морала? Сјетите се шта Митке каже о свом односу према брату у тренутку када савјетује Коштану да се помири са судбином, да се покори, да не плаче.

- Видимо да је Митке у сукобу са патријархалном средином, а да истовремено и сам усваја патријархална схватања. Како се то двојство, та противрјечност одражава на личност? Како се испољава?

Подстичемо ученике да закључе како Митке свој сукоб са средином доживљава истовремено и као сукоб са самим собом. Он је изразито сложена природа, растрзан је унутрашњим конфликтима, борбом срца и разума, пушта осјећањима на вољу, а истовремено их сам ограничава и спутава. „Више у механу - не! Вино - не! Песна - не! Дом, уз огњиште!“ (Станковић 1983: 76).

Миткова патња је израз незадовољства постојећим и датим. Он је недоречени побуњеник против владајућег реда и морала. Супротставља се стварности ничим другим сем сопственим болом и понекад пркосом. Његова туга и песимизам нијесу само израз незадовољства постојећим и датим, већ 
израз узалудности одгонетања смисла људског живљења уопште. Његов носталгични немир није чежња за нечим сасвим одређеним и реално пропуштеним у животу. Да је тако, његова жал би била банална а велики лик врањанског пјесника изгубио би поетски чар тајанства.

- Какве је врсте Миткова љубав према Коштани? Има ли у њој похоте и тјелесне пожуде?

- Кажите и објасните идеју драме. Прокоментаришите исказ: „А човек је само за жал и за муку здаден”. Како сте то разумјели? Из какве перспективе провијава њихово животно искуство?

Миткова љубав према Коштани је без еротске пожуде. Једини се Митке сјетио да на дан свадбе дарује Коштану. Посебно је специфичан дијалог између Митка и Коштане у четвртом чину. Ту Митке износи велику ствар о човјеку, његовом животу и његовој судбини. Он не вјерује у награду на ономе свијету, нити се плаши казне за своје гријехове према жени и дјеци. Наравно, при откривању идеје очекујемо извјесна лутања и наслућивања. Настојаћемо да се идеја дјела открије у шире схваћеним Митковим ријечима: „Дигни се! Будни човек!“‘

Наглашавамо да је писац подвукао ријеч човјек, што значи да је треба схватити са свим атрибутима људског и хуманог. Ријечи су упућене Коштани, али се, са оптужујућим призвуком, односе на средину. Човјек си ако разумијеш и поштујеш друге, ако им не спутаваш личну слободу, ако схваташ глас њиховог срца.

- Какав је ваш општи утисак о Коштани? Које су њене доминантне особине?

- Откуд знамо да је Коштана лијепа? Да ли је писац сликао њену љепоту?

- Да ли се популарност Коштане може објаснити само њеном љепотом?

- Како се Коштана односи према животу, игри, пјесми?

- Како замишљате и доживљавате њену пјесму? Гдје се најбоље види да Коштана не пјева из користољубља?

Коштана је млада, лијепа, темпераментна Циганка. Њена љепота и њена умјетност представљају спој ватре, необуздане младости и слободе. Она је обдарена људска природа „царског грла”, која своју младост и радост живота уноси у опојну љепоту пјесме и игре. Флуид њеног магичног еротизма чини да сви губе тло под ногама. Њену пјесму обасипају дукатима. Она узима бакшиш али не пјева само за њега. Она пјева и себе ради. У 
пјесму се уноси читавим бићем. Њена префињена умјетничка душа тежи нечему вишем, неопипљивом. Дубоко загледана у гору, пита се је ли то та „голема, пуста, тамна гора” из пјесме и она осјећа њен мирис.

За њу није циганска махала са разваљеним кућама и камењем на којем ће живот и љепота да јој увену. Још мање је за њу богаташка кућа у којој ће да двори старе и ноге да им пере. Све што жели је слобода, једина њена љубав је пјесма, једини циљ „тамо”, оно „тамо” неухватљиво, недодирљиво, које човјек никада није достигао. За њом лудује Врање, али у њеној природи нема ничег разблудног, нити у њеним поступцима ичег неморалног. Добро осмишљеним методичким вођењем ученици долазе до закључка да су узроци Коштанине популарности и привлачности у њеној заносној пјесми, таленту, темпераменту и младости. Када Коштана запјева:

\author{
„Стојанке бела Врањанке! \\ Кад те је мајка родила, \\ на шта је оком гледала: \\ да ли на сунце сјајно \\ или јабланче танано? \\ Бре гиди, џанум, Стојанке, \\ Стојанке, бела Врањанке...“
}

(Станковић 1983: 47).

љепота њеног гласа залуду људе и тад настаје лом. И старо и младо за њом полуди. Пијанке, туче и пуцњаве не престају. Њене пјесме отварају срце и најтврдокорнијим патријархалцима. Она сјећа на прохујалу младост и неостварене жеље. Она је окриље за разочаране и усамљене, а њена пјесма лијек за посрнуле и унесрећене.

„Коштана отеловљује поетску слику, успомену, сан. Због тога она мора остати недохватна и недостижна за све и зато удаја окончава њену привлачност. Из иреалних идеализованих простора песме, она удајом мора прећи у реална простор, у коме нема места за недостижни поетски идеал женскости, за предмет опште жудње, већ само за обично људско биће (Пешикан-Љуштановић 2009: 11).

- Коштана је створена за пјесму и слободу, а шта је очекује? Како она доживљава насилну удају? Пратите њена реаговања и пишчев психолошки поступак. Прочитајте најизразитија мјеста. На кога она 
усмјерава своје реаговање? Како она испољава свој бол? Какве су њене реченице?

- Коју Коштанину особину уочавате у њеном односу и ставу према Стојану? Са којом мотивацијом она одбија Стојанову брачну понуду?

- Зашто ни Митке не може да јој помогне? Објасните реченицу коју изговара: „Суђенице ти досудиле”. Упоредите Коштанин лик из сцене у којој је распјевана и слободна с њеним ликом у завршној слици фаталистичког мирења са судбином „тако је писано”.

Коштана је типичан примјер трагичне жртве патријархалног реда и морала. Она је двоструко трагична јер је Циганка, из дискриминисаног рода, биће које је у деспотском друштвеном поретку лишено сваког права и које ће бити жртвовано за чаршијски ред и породични мир. Идући за основном идејом, Станковић драму завршава насилном удајом Коштане. Њу ће, обамрлу од бола, у пратњи полиције, одвести у Бању и привјенчати не за Циганина музичара, него за Циганина ковача. Таквим поступањем Коштана се одриче и себе и свога живота.

„Ох! Зар ја тамо? За Асана, у село, у Бању? Тамо? И ја његова, Асанова? Зар он мој муж? Он? Ох? (...) Све хоћу! Где су? Нека ме воде! (...) И срце, и очи, и снага, све за Асана, за село, Бању! (Станковић 1983: 71).

Посебно је важно да ученици запазе како Коштана говори емоционалним, истрзаним, екскламативним и елиптичним реченицама, што у потпуности одговара стању у којем се налази. Коштана одбија Стојанову љубоморну љубав, богаташку кућу и старе родитеље:

„Нећу! Не могу! Код тебе! Зар само код тебе? И само хаџију, оца твога и мајку твоју да дворим и да служим? Да пред њима клечим и ноге да им перем? Из собе да не изађем, већ само да седим, ћутим, трпим?“ (Станковић 1983: 69).

Није она за то, то „само” горе је и од Бање, и од Асана, и од циганске махале. Јер: ...

„Кад ноћ падне, месечина дође, сан не хвата, око се шири, снага разигра... шта онда? ... Зар да се не мрднем, из собе не изађем, већ само ту да седим, ћутим, гледам у месечину ... А ноћ дубока, месечина иде, греје, удара у чело, главу ... пали ... Шта онда? ... Ох, нећу!“ (Станковић 1983: 69).

Коштана прихвата уклетост своје судбине толико сличне судбини других Врањанаца. Сама се пење у сватовска кола говорећи својој мајци: 
„Ћути, стара!“ Ријечи јој више никада неће бити потребне. Лична трагедија Коштане и Миткова лична трагедија спајају се у епилогу. Митка јечи „беше моје!“, али не дозвољава да га жале јер се сам током живота ожалио. И он савјетује Коштану: „Дигни се! Не плачи! Слузу не пуштај! Стегни срце и трпи! Бидни човек; а човек је само за жал и муку здаден” (Станковић 1983: 77). И он и она ће плакати цијели живот. Дошла им је ноћ из које дан никада неће сванути.

- Издвојте специфичности (посебности) хаџи-Томиног лика.

- Како се он односи према Коштани?

Хаџи-Тома је домаћин, трговац, представник деспотског, патријархалног морала. Стицао је богатство током цијелог живота да би оставио сину. Међутим, ученици запажају да се испод његове привидне неосјетљивости крије исто једно несрећно људско биће као што су Митке и Коштана. И у његовој души се крије бол због промашеног живота, недосегнуте среће. Он се ломи и губи у унутрашњем сукобу између човјечности, пригушене жудње за љепшим и аутентичним - и дужности коју му налаже његов социјални статус. Хаџи-Тома не жали што син Стојан расипа, што носи свилу и срму, али упорно покушава да одвуче сина од Циганке. Међутим, све се мијења; у почетку хаџи-Тома осуђује и потцјењује Коштану, да би се на крају, задивљен Коштанином пјесмом и игром, предао севдаху.

Веома је важно да ученици закључе као хаџи-Тома потпада под утицај Коштанине пјесме, пјесме која доводи до тога да се заборавља, раскрављује, пушта срцу на вољу. Најбољи доказ за то јесу ријечи које изговара: „Доста, доста...“. Ученици закључују да изговорене ријечи најбоље илуструју хаџи-Томину борбу са самим собом, као и покушај да у тренуцима падања у севдах активира моралне кочнице (инхибицију) која ће га задржати на ивици хаџијског достојанства. Међутим, заносна Коштанина игра учинила је да се заборави на све: и на друштвени положај, и на класну припадност и на породицу. Доводи Коштану и свираче, Цигане, својој кући. Сина тјера из куће (чак му пријети и да га убије). Коштанина пјесма отвара хаџи-Томино срце, у њему буди успомене и он казује управо оно што га је цијелог живота мучило и тиштало. Ученици схватају да хаџи-Тома жали за младошћу која је прошла а није се довољно наживио и наљубио. Његово срце је жељно миловања, па је стога и неутјешно, са непреболом у себи.

- Објасните хаџи-Томину улогу у драми. 
Хаџи-Томина улога у овој драми има посебан значај. Наиме, он представља најјаче упориште патријархалног деспотизма и хаџијскочорбаџијског достојанства. Коштанин тријумф огледа се у рушењу тог упоришта, у показивању његове скривене природе. Коштанина заносна пјесма, младост и љепота, довели су до тога да и он открије незадовољство постојећим, јер то постојеће (жена, кућа) гуши и ограничава.

Стојанов лик ученици ће обрадити кроз постављање сљедећих питања:

- Опишите Стојанов однос према Коштани. Покушајте да извршите поређење Стојанове и Миткове љубави према Коштани, а исто тако, да укажете и на разлике.

- Зашто је Стојан разочаран?

- Како се средина односи према Коштаниним родитељима?

Стојан је младић, хаџијски син сав у свили и срми, који немилосрдно по кафанама расипа очево богатство. Због несрећне љубави према Коштани занемарује мајку и сестру које га воле. Занемарује кућу, обичаје и све оно што налажу неписани патријархални закони. Опчињен љубављу и љубомором одрекао би се свега и са Коштаном побјегао у свијет. Њено упорно одбијање гаси све наде и срећу и љубав, он узвикује „беше моје” јер и њему је суђено да увене због неузвраћене љубави. На основу наведеног, ученици закључују да Стојана карактерише младалачки љубавни занос, спонтаност али и наивност, као и недостатак животног искуства.

Цигани, Салче и Гркљан - Коштанини родитељи и свирачи, прате Коштану и одрађују свој посао. Они не одлучују, не питају, већ искључиво служе за увесељавање богаташа и искаљивање њиховог бијеса. У очима богаташког Врања они су нижа врста према којој се тако и понашају. Не могу спасити Коштану од насилне удаје, за њих не постоји закон, протјерују их и затварају по својој вољи, а они не смију да се супротставе.

\section{3. ЈЕЗИЧКЕ СПЕЦИФИЧНОСТИ}

$\mathrm{У}$ наставку интерпретације, ученици ће се бавити језиком ликова у Коштани. Добрим методичким вођењем ученици долазе до закључка да је драма Коштана написана живописним нарјечјем којим ликови искрено проговарају. Дијалекатска аутентичност јужноморавског дијалекта, коме припада и Врање са околином, сачувана је само у Митковом говору. Тај 
дијалекат доприноси конкретности лика, сугерише његову увјерљивост и аутентичност, појачава непосредност и спонтаност исповиједања и вјерно одражава локални колорит.

- Зашто у драми Коштана има више монолога и пјесме него дијалога?

Језик Станковићевих јунака је наизглед сиромашан јер они и јесу ћутљиви и усамљени људи, затворени у себе. Ликови се не упуштају у дијалоге који захтијевају лични тон. Садржину њиховог ћутања Станковић је изразио повратношћу и извјесном посредношћу управног говора. Митке је најговорљивији у драми, али је и његов говор монолошки. Он говори у присуству других, али се, у ствари, највише обраћа себи. Врањанци своју унутрашњост држе дубоко у себи. Њихове душевне потресе најбоље осликава то ћутање, јер проговорити значи прекршити неписани закон, преступити и показати слабост.

У Коштани се само у првој сцени императив глагола ћутати чује седам пута. Између мушкарца и жене разговора готово и да нема. Само је мушкарцу дозвољено да говори, а тај говор је обично заповијест жени. На уздах своје жене Кате, хаџи-Тома одговара: „һут! Уста да имаш језик да немаш”. (Станковић 1983:28). Ријечи откривају душу, оголијевају неку обавезно „грешну” мисао или жељу годинама скривану у себи. Међутим, када се изговоре послије толико устезања, испрекидане су, болне, блиске крику, али искрене. То је кључни разлог зашто језик Коштане одступа од језичких норми, јер њихову искреност одражава управо дијалекат којим је изговорена. Без обзира на то што Станковићева реченица крши лексичке и синтаксичке законе, она врло оригинално (изворно) износи мишљења и осјећања јунака.

\section{4. ЗАКЉУЧНА РАЗМАТРАЬА}

Завршни дио часа биће посвећен синтези утисака, расположења и ставова. Постављањем одговарајућих питања, ученици ће вршити поређење ликова:

- Упоредите ликове Митка и Коштане. Покушајте да уочите и објасните њихове сличности и разлике.

- Објасните узроке патње и бола свих ликова у Коштани.

- Каква је у основи њихова слика свијета и живота? Чиме је она условљена: 
а) индивидуалним својствима

б) друштвеним

в) несналажењем у животу

г) фаталистичким поимањем живота.

Према мишљењу Милке Андрић, проучавање Станковићеве Коштане на наставном часу требало би ,завршити разговором у функцији синтезе ученичких сазнања о лирским структурама у свету овог уметничког дела. (Андрић 1996: 104).

- Откријте шта драму Коштана чини трајно актуелном и савременом.

Заједничка особина свих ликова је усамљеност и неспокојство. Немоћни су да се одупру животној стварности и судбини, прихватају туђе одлуке повриједивши себе, своју људскост. Страх од незаслужене казне је оправдан, сви га осјећају јер су сви и кажњени. Ученици уочавају да им је заједничко и осјећање отуђености. Отуђење од породице и друштва је неминовно. Патријархално друштво својим неписаним законима одлучује формирање породице коју сви ликови у драми доживљавају као казну судбине. Породица је морање које су прихватили мимо своје воље и прихвативши је одрекли су се себе, својих потреба, жеља и сопственог живота и у пјесми прналазе спас.

„Песмом се, било да се пева или наручује, утажује бол и срце разгаљује. Недовољно смеле и отворене да своју жудњу за животом непосредније искале, Станковићеве личности се поверавају песмом или само песми. Понекад је њихов немир до те мере дубок, неодређен и потресен да се једино песмом може изрећи. Стога је овде песма не само најприкладнији већ и најпотпунији начин интимног изражавања живота, у коме је тако много забрана и покорности; и стога - иако народна - песма делује лично као да се сваки пут изнова пева" (Јовичић 1969: 545).

Судбине свих њих спаја непреболни „жал за младост”, а све разлике међу њима потире очај, ништавило и празнина промашеног живота. Разлике у особинама и поступцима Митка и Коштане првенствено су условљене разликама у полу и добу живота. Митке је, као старији и искуснији, „млого преко своју главу префрљија”, па је склон песимистичком филозофирању и неизбјежности људске трагике. Сви одметници од устаљеног реда имају свој тренутак коначног пораза и покајничког враћања томе реду и моралу. Неостварена љубав и промашени животи представљају основ патње и бола свих ликова. 
„И зато, била је Коштана тумачена као народна игра, комад $c$ певањем, само по конвенцији: по склопу приче, неповезаном и лабавом, по типовима, упрошћаваним а јасним, по песмама, старим већ познатим, и на крају, по прописаном начину извођења лакрдије, хотимице примитивном, и пуном претеривања. Ако се коме Коштана могла да чини `реална` слика из народног живота, била је онолико само колико то врста допушта. Промена конвенције, тумачење Коштане као драме, истицала је као недостатке комада, оглашавала је као мањкавост, и оно што су особине старе врсте (Бајчетић 1987: 44).

Коштана има трајну умјетничку вриједност јер је основни мотив у њој жал за младошћу. Исти је обрађен врло сугестивно и у складу са људском природом и психологијом личности. Без обзира на то ком времену човјек припадао и ма гдје живио, он у одређеним периодима свог живота, слично јунацима у Коштани, осјећа бол због пролазности живота и носталгије за младошћу.

Похвала Коштани звршава се, увек, по невољи, пописом њених драмских мањкавости, а успех код публике прати недоумица, често, и презир. Коштана је скамењени остатак старинског нашег позоришта, мисли се, нешто по врсти слично Биду и Ивковој слави, једном наивном и једном грубом комаду. Али то су пуке предрасуде критике (и тим, маргиналним мишљењима ваља дати одговарајуће место). Није криво дело, а још мање писац, кад их погрешно читају. Криво је време, извитоперени укус времена" (Бајчетић 1987: 5).

Драма Коштана садржи спој традиционалног, у теми и обради, и новог, модерног, којим је приказана унутрашња, психолошка перспектива ликова. Коштана је пуна локалног, фолклорног колорита, патријархалног оријенталног свијета, њиховог „дерта” и „карасевдаха”, врањанског дијалекта, пјесме и игре, „жала” што је старо прошло, што су младост, љубав и живот прошли, и представља једно од најбољих Станковићевих дјела.

\section{ЛИТЕРАТУРА}

Андрић, М. (1996). Методички прилази књижевноуметничком делу. Београд: Друштво за српски језик и књижевност. [Andrić, М. (1996). Metodički prilazi književnoumetničkom delu. Beograd: Društvo za srpski jezik i književnost.] 
Бајчетић, П. (1987). „Драмска прича”, у књизи: Борисав Станковић, Драме, приредио Предраг Бајчетић, Београд: Нолит. [Bajčetić, P. (1987). „Dramska priča”, u knjizi: Borisav Stanković, Drame, priredio Predrag Bajčetić, Beograd: Nolit.]

Илић, П. (1998). Српски језик и књижевност у наставној теорији и пракси. Нови Сад: Змај. [Ilić, Р. (1998). Srpski jezik i književnost u nastavnoj teoriji i praksi. Novi Sad: Zmaj.]

Јовичић, В. (1969). „Песма и певање у књижевном делу Борисава Станковића”, Летопис Матице српске, књ. 404, св. 5, Нови Сад, новембар, стр. 545-554. [Jovičić, V. (1969). „Pesma i pevanje u književnom delu Borisava Stankovića”, Letopis Matice srpske, knj. 404, sv. 5, Novi Sad, novembar, str. 545-554.]

Марјановић П. (1985). Борисав Станковић: „Коштана”, Југословенски драмски писии XX века I. Нови Сад: Академија уметности. [Marjanović, P. (1985). Borisav Stanković: „Koštana”, Jugoslovenski dramski pisci XX veka I. Novi Sad: Akademija umetnosti.]

Николић М. (2006). Методика наставе српског језика и књижевности. Београд: Завод за уџбенике и наставна средства. [Nikolić, M. (2006). Metodika nastave srpskog jezika i književnosti. Beograd: Zavod za udžbenike i nastavna sredstva.]

Палавестра, П. (1960). Борисав Станковић - избор. Сарајево: Свјетлост. [Palavestra, P. (1960). Borisav Stanković - izbor. Sarajevo: Svjetlost.]

Пешикан-Љуштановић, Љ. (2009). Кад је била кнежева вечера. Музеј позоришне уметности Војводине, Нови Сад. [Pešikan-Ljuštanović, Lj. (2009). Kad je bila kneževa večera. Novi Sad: Muzej pozorišne umetnosti Vojvodine.]

Predmetni program za predmet Crnogorski jezik i književnost za I, II, III i IV razred opšte gimnazije (2011). Podgorica: Zavod za školstvo.

Протић, М. (1972). Бора Станковић према нашем реализму ХІХ века. Српска књижевност у књижевној критици, Београд: Нолит. [Protić, M. (1972). Bora Stanković prema našem realizmu XIX veka. Srpska književnost u književnoj kritici, Beograd: Nolit.]

Rosandić, D. (1978). Književnost u osnovnoj školi. Zagreb: Školska knjiga.

Станковић, Б. (1983). Коштана. Београд: Просвета. [Stanković, В. (1983). Koštana. Beograd: Prosveta.]

Veselin R. Bulatović

\section{METHODICAL APPROACH TO THE DRAMA KOŠTANA BY BORISAV STANKOVIĆ}

\section{Summary}

The contemporary methodical approach to Koštana, a drama written by Borisav Stanković, implies that teaching should be adapted to conditions of the work, students and their abilities and interests, as well as the available time. The quality depends on these 
factors and if any of them are absent, the teaching will not meet the required criteria. Successful methodical solutions are achieved through the special settings of forming elements in each literary work. The teacher must not impose their solutions in interpreting the literary work, but primarily mediate in communication between the students and the work, encouraging creative spirit and participation in the analysis. In order to meet these demands, it is necessary to continuously follow modern tendencies in contemporary culture and literature, current literary production, and especially works that arouse special attention of the literary public, such as Stanković's literary achievements.

Previous methodological experience has shown that a successful analysis of Stanković's Koštana especially contributes to the teacher's ability to predict, find and encourage effective forms of educational communication of students with the aesthetic world of the literary work. In this way, it is the core of teacher's preparation, the operational prediction and professional conditioning of goals and directions of the work, that is, planning the original approaches and functional procedures which will enable the experienced engagement, creativity-research and critical action of students. In problematic and research approached, creating effective ways of working and motivating students is adjusted to finding a methodology to enrich and go beyond the contemporary methodological experience. Hence, the aspiration and efforts towards original work and inventive treatment are the basis and starting point in which all good efforts and activities of both teachers and students are met.

Keywords: methodical approach, drama, dramatic action, research assignments.

Primljeno: 26.3.2017. Prihvaćeno: 14.11.2017. 